\title{
Brasil Nomadic Furniture 4.0 Brasil Nomadic Furniture 4.0
}

\section{fauusp mestrado}

\section{Amanda Aline Alves de Oliveira, Tatiana Sakurai}

OLIVEIRA, A. A. A.

Graduada em Arquitetura e Urbanismo (2014) pela Universidade Federal de Ouro Preto. Foi membro do grupo de pesquisa NEC e aluna do IAU USP (2012).

Cursa o Mestrado na FAU USP (2018) e é membro dos grupos de pesquisa: DIGIFAB e Café com Pesquisa.

Graduated in Architecture and Urbanism (2014) from the Federal University of Ouro Preto. She was a member of the research group NEC and student at IAU USP (2012). She is currently doing a Master's in Design at FAU USP (2018) and integrates the research groups: DIGIFAB and Coffee with Research.

\section{SAKURAI, T.}

Professora Doutora nos cursos de Arquitetura e Urbanismo e Design da Universidade de São Paulo.

Possui interesse de pesquisa em: mobiliário doméstico, design de interiores; design para a experiência; sustentabilidade.

Professor of Architecture and Urbanism and Design at the University of São Paulo. Her research interests include: home furnishings; interior design; design for experience; sustainability.

\section{contato} amandaaline212Qusp.br tsakuraidusp.br
Como motivação de análise para a pesquisa de mestrado Brasil Nomadic Furniture 4.0, busca-se encontrar soluções no campo do mobiliário residencial para jovens entre 15 e 29 anos em situações de constantes deslocamentos territoriais. Para tanto, prioriza-se o estudo de móveis desmontáveis e compactáveis obtidos a partir da marcenaria tradicional e digital e das soluções provenientes das mesmas, vindas através de sistemas de encaixes, articulações e sistemas de deslizamento. Estas condições são analisadas dentro do âmbito proporcionado pela capital paulista, onde se encontram os doze Fab Labs Livres SP. Assim, cria-se um cenário no qual é possível abrir perspectivas para que estes jovens se apropriem destes laboratórios de fabricação digital e criem seus próprios móveis. A pesquisa parte da atualização e adequação para a realidade brasileira dos livros Nomadic Furniture e Nomadic Furniture 2, dos autores James Hennessey e Victor Papanek, ambos escritos na década de 1970. Estes livros são constituídos por uma série de móveis pensados dentro da lógica do Do-lt-Yourself para serem apropriados pelos leitores, de forma que os móveis apresentados possam ser modificados e aprimorados pelos interessados. Assim, este estudo obterá como produto final a contribuição para a criação de um catálogo deste mobiliário que, em conjunto com a análise das condições brasileiras encontradas em sua catalogação, permitirá conhecer a produção de móveis desmontáveis e compactáveis no Brasil.

Palavras-chave: Desmontabilidade; Encaixes; Fabricação Digital; Mobiliário; Mobilidade
As a motivation factor for the analysis of the Master's research Brazil Nomadic Furniture 4.0, we seek to find solutions in the field of residential furniture for young people between 15 and 29 years of age in situations of constant territorial displacement. Therefore, the study of demountable and compactable furniture created through traditional and digital woodwork, and from solutions coming from them through systems of fittings, joints and sliding, is prioritized. These conditions are analyzed within the scope provided by the city of São Paulo, where the twelve Fab Labs Livres SP are located. It results in, a scenario in which it is possible to open up perspectives for these young people to benefit from these digital manufacturing laboratories creating their own furniture. The research is based on updates and adaptations to the Brazilian reality of Nomadic Furniture e Nomadic Furniture 2, books by James Hennessey and Victor Papanek, both written in the 1970s. These books consist of a series of furniture designed within the logic of Do-It-Yourself to be applied by readers so that the furniture presented can be modified and improved by those interested in it. Thus, the outcome of this study will be its contribution to the creation of a catalog of this kind of furniture which, together with the analysis of the Brazilian situation found in its cataloging, will allow better knowledge of the production of dismountable and compactable furniture in Brazil.

Keywords:Disassembly; Fittings; Digital manufacturing; Furniture; Mobility realização

ppgdesign_fauusp
5 dezembro 2018

cidade universitária, são paulo, sp 